\title{
The Chiapas Rebellion and the Failure of Mexico's Indigenous Policy
}

\author{
By Rainer Grote
}

\section{Introduction}

Of all Latin American countries, Mexico is the one with the largest autochthonous population and the greatest diversity of indigenous peoples, although in some countries (Guatemala, Peru, Bolivia) their respective demographic weight with regard to their share of the total population may be more significant. ${ }^{1}$ According to official estimates, today more than seven million Mexicans, or 9 percent of the total population, speak an Indian language or dialect, a number which is likely to increase when other non-linguistic criteria - like religion, adherence to Indian custom, cultural traditions etc. - are taken into account. ${ }^{2}$ Among the indigenous population, 56 different ethnic groups have been identified by the Mexican National Indigenous Institute (Instituto Nacional Indigenista - INI). ${ }^{3}$ The predominant indigenous language is Nahuatl with more than one million speakers, followed by Maya (approximately 700.000), Mixtec and Zapotec (roughly 400.000 speakers each). Most of the indigenous groups - about 90 percent - are living in the centre, the Southwest and the Southeast of Mexico. They play a numerically important or even dominant role in the states of Yucatan, Quintana Roo, Oaxaca, Chiapas, Hidalgo, Campeche, Puebla, Guerrero, Vera Cruz and San Luis Potosí. ${ }^{4}$

Although Mexico was the first Latin American country to develop an official policy toward its indigenous communities with the creation of the National Indigenous Institute in 1948, until recently Mexico's indigenous people did not enjoy any distinct legal status within the Mexican constitutional system. The Constitution of 1917, which introduced a certain number of social rights in favour of formerly underprivileged groups, especially of those

1

Manfred Wöhlke, War Chiapas nur ein Vorspiel?, Stiftung Wissenschaft und Politik - AP 2882, January 1995, p. 30.

2 Jorge Madrazo, L'adición al Artículo $4^{\circ}$ constitucional en materia indígena, in: Instituto de Investigaciones Jurídicas, Modernización del derecho mexicano - Reformas constitucionales y legales 1992, México 1993, p. 22.

3 A complete list of these groups is given by Jorge A. Vargas, NAFTA, the Chiapas Rebellion, and the Emergence of Mexican Ethnic Law, 25 California Western International Law Journal (Fall 1994), p. 45 , note 274.

4

Wöhlke, supra note 1 , p. 31 . 
Mexicans who lived as peasants or campesinos in the countryside, into the national legal system conspicuously abstained from any direct reference to the needs and rights of the indigenous peoples. It was not until 1992 that, by means of an amendment to Article 4 of the Constitution, the pluriethnic composition of the Mexican nation was officially recognized and the constitutional foundation for a special protection of their languages, customs, social organizations and economic resources was established. Despite recent attempts at legal reform, however, Mexico's indigenous peoples continue to suffer from a silent but pervasive discrimination in almost all areas of daily life. Their misery attracted international attention when in January 1994 the Indian rebels of the Zapatista National Liberation Army (Ejército Zapatista de Liberación - EZLN) rose in arms to extract an immediate response from the national government to the constant and massive violation of their political, economic and social rights in Mexico's most southern state. In the summer of 1995 it was not yet clear whether the complicated dialogue between the government and the Indian rebels would lead to any significant and lasting changes in Mexico's indigenous policies.

Against this backdrop, the following essay will give an historical overview of the different stages of government policy toward the indigenous communities living in the Mexican territory since the colonial period (II). It will then examine the current economic and political situation of Mexico's indigenous groups (III) before turning to an analysis of recent changes in Mexican legislation and of their practical significance with regard to a more effective protection of the Indian population (IV). In this context it will be necessary to consider more closely the oligarchical power structures still existing in many parts of Mexico which constitute a formidable obstacte to any real progress in this area, as recent event in Chiapas have shown once more (V). Finally, the concluding remarks will evaluate the changes needed in Mexico's legal and political system to put an end to the worst abuses of indigenous rights (VI).

\section{The official Mexican policies toward the indigenous communities since the Conquest}

\section{The policy of paternalistic guardianship during the colonial period}

The Spanish conquest of the Aztec empire and the destruction of its capital Tenochtitlan in 1521 had a devastating impact upon the Indian population which lived in the territory that constitutes present-day Mexico. The Indians lost their best lands and water supplies and decreased significantly in number. Although the number of Indians in New Spain - the name the Spaniards had given to the newly conquered region - has long been a matter of controversy; it is evident that during the sixteenth century epidemics and periods of famine ravaged among the indigenous population and reduced its total to approximately two or 
three million. ${ }^{5}$ This tremendous change vastly reduced the social complexity of indigenous communities and paved the way for the emergence of the colonial society with its typical mixture of Spanish upper class, including both Iberian-born Spaniards (gachupines) and American-born Spaniards (criollos), and Indian lower class. The Indians retreated, both geographically and socially, and reemerged at the community level as new entities, composed entirely of local peasants, which soon developed into bastions of economic and cultural self-sufficiency.

In the early stages of Spanish rule, two conflicting views regarding the treatment of the Indians emerged. The prevailing view, which was expressed by writers like Ginés de Sepúlveda and Solózano Perreira, claimed the natural inferiority of the Indians, based on their "barbarous manners" and their "lack of intelligence". The Law of Nature itself, it was alleged, provided for the submission of the indigenous peoples to the Spaniards, the Spaniards being the one who would elevate them to a civilized life. ${ }^{7}$ On the other hand, thinkers like Bartholomé de las Casas strongly defended the Indians, arguing that they were creatures of God, who shared in all human attributes and had been endowed with intelligence, thus having the right to live as free persons within a civil society. ${ }^{8}$ The Spanish crown officially did not approve of either viewpoint, changing from one position to the other, in accordance with the practical requirements of the moment.

The colonial institutions set up by the Spanish rulers favoured the economic exploitation of the Indian population who were often regarded as a "natural resource" by the local elites. One of the most important economic measures of the early colonial period was the creation of encomiendas, divisions of land inhabited by Indians which were granted by the Crown to Conquistadores and Spanish colonists in order to encourage the settlement in the newly conquered territories. The encomenderos were assigned the task to convert to Christianity the Indians living within the boundaries of their encomienda and to maintain the public order. In return, they had the right to collect tribute from the Indians and to demand personal services. This system, which favoured the repression and exploitation of the Indian population and was therefore sharply criticized by Bartholomé de las Casas and other advocates of indigenous rights, was not abolished until $1721 .{ }^{10}$ Another instrument of

5

Guillermo Floris Margadant, Official Mexican Attitudes Towards the Indians: An Historical Essay, 54 Tulane Law Review (1980), pp. 965/966.

6

Thomas E. Weil / Jan Knippers Black/Howard I. Blutstein / Kathryn Therese Johnston / David S. McMorris, Area Handbook for Mexico, $2^{\text {nd }}$ edition, Washington 1975, p. 87.

7 Rodolfo Stavenhagen, De Cómo Subjugar a los Naturales, in: Derecho indígena y derechos humanos en América Latina, México 1988, pp. 15/16.

8

Id. at p. 17/18; see also Madrazo, supra note 2, pp. 23/24.

9 Vargas, supranote 3, pp. 38/39.

10

Stavenhagen, supra note 7, p. 21. 
colonial government was the institution of repartamiento, a rotation system under which Indians were forced to work for the colonial economy. Indian villages were obliged to put men not strictly necessary to the village economy at the disposal of the State, the church or some privileged individuals. ${ }^{11}$ At the same time, the Spanish Crown issued several rules designed to protect basic economic needs of the indigenous communities by prohibiting grants to Spaniards of land and water rights which might inf ringe upon systems of real property in local Indian villages. But the great epidemics of the sixteenth century helped to undermine this policy, since they drastically reduced the size of many Indian communities and their demand for land. As a result, many of the Indian communal lands were taken over illegally by Spaniards, who were sometimes acting in collusion with the local caciques. ${ }^{12}$

In the political realm, governmental changes were imposed in a rather superficial way by the Spanish rulers. In the sparsely populated areas of Northern Mexico the Jesuit and Franciscan missions came to the basic instruments of public administration, whereas the large Indian nations of the center and south were broken up and reduced to their constituent city-states. In these areas, the Spanish governed through the intermediary of the local caciques, an extension of the Indian nobility which had governed the towns or villages during the preconquest period. The Spanish treated the caciques, as leaders of the Indian community, with considerable respect, according them social privileges not available to ordinary Indians. ${ }^{13}$ The colonial government created a special legal regime for the Indians, which set them apart from the rest of the population. They were required to live in their own villages or in special sections of the colonial cities. Indigenous laws and customs that were not in opposition to the Crown or the Church were tolerated. ${ }^{14}$ Indians had to pay a special annual per capita tax, but were exempt from several other taxes levied on the white population. It was officially prohibited to seize and sell Indian lands for the purpose of debt-enforcement - a protective measure which had the perverse effect of making forced labour of Indians at the service of creditors more frequent. ${ }^{15}$ On the other hand, Indians, although officially declared "free subjects of the Crown", were not permitted certain activities which were considered to be attributes of Spanish power, like horse riding or the carrying of arms. ${ }^{16}$ On the whole, Spanish legislation tended to reinforce the isolation of the indigenous peoples within the colonial society. When Alexander von Humboldt visited New Spain at the end of the colonial era, he observed that the Indians constituted a separate

Id. at p. 971.

13

Weil, supra note 6, p. 55 .

Stavenhagen, supra note 7, p. 18.

15

Margadant, supra note 5, p. 973.

Stavenhagen, supra note 7, p. 18. 
nation, "privileged by law but humiliated by everyone, with no communication with Spaniards or mestizos because of the laws"17.

\section{The emergence of legal equality as the guiding principle of official Mexican attitudes toward Indians after the Independence}

When Mexico acquired independence in 1821, the policy of official guardianship pursued by the Spanish Crown, which had tried to secure a certain degree of protection for Mexico's indigenous groups through the establishment of special legal rules (although they were often ignored in practice by colonists and corrupt officials) was completely abandoned. For more than a century, the Republic of Mexico did not have an official policy toward its indigenous communities. The new constitutional order, which was inspired by the principles of the American Constitution and the French Revolution, rested on the notion of legal equality. The principle of legal equality was designed to embrace all the new citizens of Mexico, whether they were criollos, mestizos, Africans, or Indians. The Plan of Iguala of February $1821^{18}$ declared that all Mexican nationals were citizens, without further distinctions. Indian tributes were abolished, and in 1822 mention of racial origin in official documents was forbidden.

The legal equality granted to all Mexicans, however, did not help improve the well-being of the indigenous groups which still constituted the majority of Mexico's population at the time of its independence. ${ }^{19}$ On the contrary, of ficial equality exposed Mexican Indians to the adverse effects of economic modernization. A bulwark in the preservation of Indian traditions had been communal property. Yet, collective ownership was under constant attack during the period of political and economic liberalism which followed independence. After 1825, laws were passed in several regions of Mexico which provided for the subdivision of communal property into private lots. The indigenous communities did not go along with these reforms, fearing that white people from outside would obtain holdings in the formerly communal lands, thus threatening their lifestyle and opening up their closed societies. The Indian land situation worsened further when in the second half of the nineteenth century government-supported companies with private capital were authorized to locate land and form medium-sized lots which the Mexican government would then make

According to Silvio Zavala, "Instituciones indígenas en la Colonia", in: Instituto Nacional Indigenista, Métodos y resultados de la politica indígenista in México, México 1973, Chap. VI, quoted by Stavenhagen, supra note 7, p. 19.

This plan, issued by Agustín de Iturbide and Vicente Guerrero, proclaimed the independence and sovereignty of New Spain and dealt a fatal blow of the Spanish colonial rule in Mexico, see Weil,

19 supra note 6 , p. 63 .

Madrazo, supra note 2, p. 22. 
available to immigrants or Mexican peasants. ${ }^{20}$ These companies were harsh in their treatment of the Indians, who often did not have clear documentary title to their land, or were unable to take advantage of protective legal arguments. The policy of the companies - to create a middle class of farmers and to attract immigrants finally failed, and the companies sold much of the land they had purchased to large haciendas. As a result, the decrease in land held by the Indians coincided with the development of large private holdings, latifundios, which were widespread by the end of the nineteenth century. Government measures designed to help the Indians in defending land they actually possessed had little effect, since the indigenous communities were not always prepared to take advantage of Mexican laws and government officials sometimes proved unwilling to assist the Indians. ${ }^{21}$

During this period the white elite of Mexico was ambivalent in its opinion of the Indians. On the one hand, there was an increasing interest in Indian history and Indian languages. Historic Indian figures like Cuauthemoc, the last Aztec emperor, underwent a dramatic reevaluation during the late nineteenth century. The prevailing view of the Indians, however, was an essentially negative one. The tribalism of the Indian and his alleged reluctance to participate in the civic affairs of the nation were seen as a grave impediment to the development of a real national community. Besides, the Indian's obstinate attachment to communal land seemed to be contrary to the requirements of a modern economy. Some commentators even went so far as to describe the Indian as a "parasite on the national tree", since it was assumed that his lack of entreprenurial spirit prevented the benefits of the new economic policy from spreading throughout the country. ${ }^{22}$ The solution generally proposed was to transform the Indian into a good liberal citizen and a responsible private property owner. However, few efforts were made to provide a better public education for the indigenous population. Quite on the contrary, the "Indian problem" got worse in the second half of the nineteenth century, when acts of arbitrary dispossession and other injustices committed on the Indians by criollos and mestizos in the wake of the privatization of communal lands triggered numerous violent Indian revolts in different parts of the country, especially in Chihuahua and Chiapas, which in turn led the Government to take severe measures of repression against the native communities involved. ${ }^{23}$

Id.

22

23

Id. at p. 980 .

Vargas, supra note 3 , p. 40. 


\section{Assimilation policies and mestizaje since the Mexican Revolution}

The Mexican Revolution of 1910 embraced important goals and aspirations advanced by the indigenous people of Mexico. In his plan of San Luis Potosí, which initiated the Revolution, Francisco Madero explicitly acknowledged that many Indians in the past had been disposed of their lands due to abuse of the law. ${ }^{24}$ The Revolution anchored collective property of communal lands firmly within the constitutional order. However, the Constitution of 1917, one of the most important consequences generated by the Revolution, referred to the demands advanced by the indigenous people only in a general and indirect manner. It did not contain any provision which explicitly recognized the rights or the existence of indigenous communities. The right to possess land as a personal patrimony to be used for agricultural purposes, which most autochthonous groups had insisted upon since colonial times, found only a brief and indirect reference in Article 27 of the Constitution. This Article granted "communal lands to rural communities" in order to constitute collective ejidos. Yet, it did not use the word "Indian" or any similar terms which could have been interpreted as giving a specific legal status to the indigenous peoples. Although the Mexican Constitution of 1917 introduced a number of so-called social rights in favour of formerly underprivileged groups into the Mexican legal order ${ }^{25}$, it was completely silent on the "Indian problem". Similarly, the Constitution did not provide for a separate representation of Indians in the political organs at the federal level or in the states. Their needs and rights were virtually ignored in the document which finalized the momentous political and social changes their protest movement had helped to bring about. ${ }^{26}$

The era that began with the Mexican revolution catapulted Mexico's Indians into a new phase of integration. The decreasing number of whites and the growing number of mestizos who were to constitute the dominant ethnic element of any future Mexican society led to the emergence of mestizaje as a new model for national integration. This view reflected the growing number of mestizos who were to constitute the dominant ethnic element of the future Mexican society. The mestizo increasingly came to be seen as combining the best elements of the two different races which had contributed to his making and as a symbol of the new Mexican nation. ${ }^{27}$ Gradually mestizos took over the reins of government at all levels of the state, from the presidency to officials in mixed Indian-mestizo villages. In this context, the existence of separate indigenous communities at the margins of Mexican

Id. at pp. 40/41.

See Article 123 of the Constitution of 1917 which contains a number of specific rights for workers, day labourers, employees, servants and craftsmen.

Salomón Nahmad, Indigenismo y oficial y luchas indígenas en México, in: Stavenhagen, supra note 7, p. 303.

Stavenhagen, Pensar a los Indios, Tarea de los Criollos, in: Derecho indígena y derechos humanos en América Latina, supra note 7, p. 30. 
society was viewed as a serious obstacle to the achievement of national unity. ${ }^{28}$ The full participation of the Indian in the political, economic and social life of the nation thus became an important objective of government policy. Government incentives were primarily aimed at distributing land to indigenous communities and improving educational opportunities for Indian children. In 1936, under President Lázaro Cárdenas, the Autonomous Department of Indian Affairs was established, followed the next year by the Department of Indian Education. The most important agency, the National Indigenous Institute (Instituto Nacional Indigenista - INI) was created in 1948. The INI was originally charged with the coordination of government actions in Indian areas in the fields of economic development, improvement of public inf rastructure, agriculture, educational policy etc., but rapidly developed its own projects and programs, sometimes in cooperation with other government agencies. ${ }^{29}$ The central policy of the INI, at least during the first decades of its existence, was to integrate the indigenous nucleus into Mexican nationality which was seen as a necessary prerequisite for Mexico's successful transformation into a modern country. ${ }^{30}$ The Indians had to become aware of belonging to the Mexican state. Since the indigenismo of this period continued to regard the Indian as economically and culturally backward, his assimilation into the mainstream of Mexican life by means of mestizaje appeared as a desirable goal. $^{31}$

An important aspect of the assimilation policy was the attempt to incorporate Indian children into the mestizo society by teaching them Spanish. Indian children had to go to schools and follow the regular academic programm designed by mestizo bureaucrats to educate mestizo children. Since Indian children were considered to be exactly the same as the mestizo children under Mexican law, it was felt that any education policy which treated Indian children differently from mestizo children would not only be unnecessary, but also improper. Later on, a more flexible approach was adopted, which distinguished between the six years of elementary school, when the children's own language had to be used, and subsequent studies, which were imparted in Spanish only. The main thrust of the education policy, however, remained virtually unchanged, since the teaching of Indian languages was still not considered as an end in itself, but merely as a didactic means to facilitate the transition to Spanish. It was not until the early 1970s that the "policy of assimilation" came under heavy criticism from teachers and indigenous organizations and was finally abandoned in favour of the principle of bilingual-bicultural education. ${ }^{32}$

Id. at p. 31 .

Tania Carrasco, Teoría y Práctica del Indigenismo, in: Stavenhagen, supra note 7, pp. 117/188. 


\section{The current economic and political situation of Mexico's indigenous groups: an overview}

\section{The failure of assimilation policy: the continuing economic and social marginalization of Indians in Mexico}

Over the last few decades the hope that the "Indian problem" might simply disappear as a result of successful assimilation policies have increasingly vanished. At the same time, the basic assumption behind assimilation policy, i.e. the belief that racial discrimination is alien to a society which explicitly recognizes the principle of intermixture of Indian, Negro and white blood as the basis of nationhood has proved largely illusory. ${ }^{33}$ Although as a consequence of mestizaje it has become more difficult to establish a clear distinction between Indians and mestizos on purely ethnic criteria - a tendency which has been greatly helped by official attempts to mask problems of racial discrimination behind the struggle against economic and social inequalities, thereby denying the racial origin of certain social conflicts - racial discrimination continues to exist as a silent but constant phenomenon of Mexican society. It is evident from the close relationship which can be found, in Mexico as well as in other Latin American countries, between the miserable economic and social situation of some parts of the population and their particular ethnic status based on the (dark) colour of their skin, their language and their customs. ${ }^{34}$

The underprivileged role of indigeous groups in Mexican society is confirmed by recent findings of the competent government departments. According to these findings, approximately 70 percent of Mexico's indigenous communities are living in rural areas. Most of them practice the traditional forms of agriculture, using primitive technology to grow the agricultural products - corn, beans, vegetables - necessary for their subsistence. In some cases, they supplement the traditional farming with the cultivation of commercial crops, most frequently of coffee. Two thirds of Mexico's coffee producers are Indians who own one third of the land used for the cultivation of coffee and account for 30 percent of the national coffee production. ${ }^{35}$ On the other hand, very few Indians dedicate their activities exclusively to commercial farming. In the coastal regions fishing has become a major economic activity for some indigenous groups. Another potentially important source of revenue is the ecologically sustainable exploitation of the rain forest and its resources. ${ }^{36}$

Stavenhagen, supra note 27, p. 30.

Wöhlcke, supra note 1, pp. $37 / 38$.

Id. at pp. $38 / 39$.

These and the following observations are based on the data provided by the Mexican government in its Ninth Report to the Committee on the Elimination of Racial Discrimination on the implementation of the International Convention on the Elimination of all Forms of Racial Discrimination, CERD/C/260/Add. 1 (1994). 
In addition to subsistence farming, a considerable number of Indians temporarily leave their homes to earn their living as agricultural workers in one of the bigger agricultural production centers. In many cases the income earned by the migratory workers, who of ten travel a thousand kilometres and more to find a job, is an important supplementary source of revenue for indigenous communities. In recent years, however, it has been affected by the crisis of the agricultural sector. ${ }^{37}$ There is also a permanent migration of Indians from the countryside to urban areas, especially to the capital. The percentage of Indians who move to the big cities is comparatively low, because most Indians are deeply rooted in their native communities and risk to lose their identity in urban areas. Those Indians who chose to live in the big cities, attracted by the prospect of better living conditions, especially with regard to food, public transport and communications, usually belong to the poorest and most marginal sectors of the population. Moreover, they are often forced to hide their identity if they want to avoid discriminatory treatment by the non-Indian population. ${ }^{38}$

In theory, the territories inhabited by the indigenous communities offer sufficient resources for a successful economic development. ${ }^{39}$ In practice, however, they rarely possess the necessary financial and technological means for a successful exploitation of their lands. Most of the parcels cultivated by Indian peasants are too small to yield sufficient crops. ${ }^{40}$ Moreover, the exact legal status of these lands is subject to uncertainty. The indigenous community up to now has not been officially recognized as a specific category of collective land ownership. The right of the indigenous groups to use and distribute their land has not yet been regulated by law, thus lacking legal enforcement and official recognition (see IV.3 below).

In addition, the natural resources of the Indian territories have been exploited by powerful interest groups at the detriment of the local indigenous communities. Some of these activities, like the massive cutting of timer and extensive cattle breeding, have proved extremly harmful to the indigenous communities, depriving them of their natural resources and threatening them with the pollution of their water and the desertification of their lands. ${ }^{41}$ In the past, powerful alliances of land-owners, ranchers, corporations and local politicians seem to have been highly successful in pushing the Indians, who were generally left unprotected by the national government, ever further to the margins of Mexican society.

CERD/C/260/Add. 1, para. 17.

CERD/C/260/Add. 1, paras. 44, 45.

Eight percent of the national territory are officially owned by indigenous communities according to government estimates, see CERD/C/260/Add. 1, para. 34. 
The Mexican government, instead of applying the law, usually turned a blind eye to constant and pervasive violations of indigenous rights (see $\mathrm{V}$ below).

As a result, the indigenous communities generally belong to the most marginal sectors of society. According to the National Population Council (Consejo Nacional de Poblacion CONAPO) 96,5 percent of the Indian population living in rural areas are concentrated in municipal districts with a high or very high degree of marginality. Only 3,5 percent of the Indian population live in conditions of medium or low marginality, whereas 23 percent of the rural population at large fall under this category. The percentage figure of Indians living in rural areas with a very high degree of marginality is almost three times as high as their share of the total population living in rural Mexico. In 1980, of the ten federal states with the highes degree of marginality, eight were also among the top ten states with the highest figures of Indian inhabitants. ${ }^{42}$ Indians living in urban areas are by no means better off. As has already been pointed out, they belong to the poorest and most vulnerable sectors of the urban population and are of ten forced to hide their identity to avoid discrimination. In other words, being an Indian in contemporary Mexico is in most cases synonymous with being poor. $^{43}$

In the health sector substantial portions of the Indian population, especially those living in rural areas, are not covered by any public health care at all. In some communities, more than 80 percent of the children are born without any medical assistance from outside. ${ }^{44}$ The majority of the Indian population in rural areas does not have access to drinking water or to public sewage.

Members of indigenous groups are frequently affected by malnutrition. According to government estimates, the percentage number of children under the age of four who suffer from malnutrition varies in the states with the highest concentration of indigenous groups from 29 percent in San Luis Potosí and Quintana Roo to 53 percent in Oaxaca, a rate likely to increase when only the children in Indian communities are taken into consideration. The Mexican government explicitly recognizes that these high rates of malnutrition cannot be explained with deficiencies in the traditional Indian diet. At the same time, it points out that in general indigenous groups do not benefit from public aid programs.

CERD/C/260/Add. 1, paras. 41 to 43

CERD/C/260/Add. 1, para. 46.

CERD/C/260/Add. 1, para. 52.

45 More than 90 percent of the Indian population in rural districts lack sewage, see CERD/C/260/Add. 1, para. 54.

46

CERD/C/260/Add. 1, para. 53. 
The members of the indigenous communities also have insufficient access to the public education system. Less than one in five children in the bilingua education system finishes primary education, compared with almost fifty percent in the national average. This is partly due to the lack of teachers who are fluent in the indigenous languages. More than 60 percent of primary schools in the bilingual system have only one teacher to attend to the different grades or are not able to offer all grades. There is no specific system to promote the education of Indians after primary school. Although there are some 5,000 public grants for Indians studying in middle schools, the amount paid under these grants is too low to constitute a real stimulus for further studies. ${ }^{47}$

The public infrastructure in the indigenous territories is insufficiently developed. Many Indian communities are still not connected to the public road system and therefore remain isolated. The lack of public roads in these areas is not only due to difficult topographical conditions, but also to the low priority given to public infrastructure projects in Indian territories. Many roads which exist have been built by the indigenous communities themselves. ${ }^{48}$ A very significant number of indigenous communities lack access to the most basic means of communication: phones, post and telegraph offices, radiostations. ${ }^{49}$ Although major progress in the electrification of the countryside has been made, many indigenous groups in the more remote areas of the country are still deprived of electricity. They often do not have the money to pay for electrification, but are prepared to help with their labour and the materials which can be found in the region in the realization of the project. ${ }^{50}$ Finally, virtually no indigenous group has benefited from one of the great irrigation projects which have been carried out in Mexico over the last years. On the other hand, indigenous communities have repeatedly been subject to resettlement measures made necessary by the irrigation projects, which sometimes resulted in a net deterioration of their living conditions. 51

The Mexican government has tried to improve the economic and social conditions of the Indian communities by a number of programs, the most important of which are the National Solidarity Program (Programa Nacional de Solidaridad) and the National Program for the Development of the Indigenous Peoples (Programa Nacional de Desarrollo de los Pueblos Indígenas). Up to now, these programs have failed to achieve any significant improvements in the miserable living conditions of Mexico's indigenous communities. The highest political priority in recent years has been given to the anti-poverty campaign known as

CERD/C/260/Add. 1, para. 55 .

CERD/C/260/Add. 1, para. 60.

CERD/C/260/Add. 1, para. 62.

CERD/C/260/Add. 1, para. 63.

CERD/C/260/Add. 1, para. 64 . 
Mexico's National Solidarity Program. Since taking office in December 1988, President Salinas de Gortari channeled $\$ 12$ billion into this program to introduce basic services and some infrastructure works in Mexico's poorest states. ${ }^{52}$ The effectiveness of the program, however, has been reduced by the opposition of local power elites which benefit from the present unequalities, and by corruption (see $\mathrm{V}$ below).

\section{Lack of effective political representation}

Despite their ongoing plight, the difficult living conditions of Mexico's indigenous peoples have until recently received little attention by government officials and national policymakers. This is due in no small measure to the fact that Indians have virtually been excluded from the political process at the federal level as well as in the states. The drafters of the Mexican Constitution paid no attention to the territories occupied for centuries by the different indigenous peoples when they determined the boundaries of the States constituting the Mexican Federation, although some of these States, which had been established during the last century in accordance with the political interests of the local criollo and mestizo power elites, were smaller in size and had fewer inhabitants than the territories occupied by the larger indigenous groups. Nevertheless, ethnic criteria were completely ignored when the State boundaries were fixed. As a result, the population of indigenous groups was frequently split up between different federal entities while their traditional territory was subdivided into several administrative districts. This policy deliberately deprived the Indians of any significant territorial power basis. ${ }^{53}$ Only at the municipal level are the administrative subdivisions sometimes consistent with the ethnic boundary lines of the local indigenous communities. These municipal districts, however, are usually too small to carry any real weight at the regional or national level. Moreover, the municipalities in general enjoy very few substantial powers within the Mexican administrative and political system. The structure of the federal system thus reinforces the political fragmentation of Mexico's Indian communities and prevents them from constituting larger and potentially more powerful pressure groups. As a practical consequence, indigenous peoples in Mexico have no political representation in the Federal Congress, and almost none in the State legislatures. $^{54}$

The problem of effective participation of Indians in the political process is worsened by the structure of Mexico's party system. For the last six decades, the country has known a de facto one-party rule with the governing Institutional Revolutionary Party (Partido Revolu-

\footnotetext{
52

53

54

Vargas, supra note 3, p. 10.

Nahmad, supra note 26, p. 304.

Vargas, supra note 3, p. 42.
} 
cionario Institucional - PRI) being in firm control of all sectors of Mexican public life. Under this system, no authority, from a modest police officer to the Governor of the State, can serve in any public capacity at the municipal, state or federal level unless they are an official member of the PRI. The PRI leaders have insisted upon maintaining token opposition, but the opposition parties represented in the federal and the state legislatures have played a merely symbolical role during most of this time. The lack of any real party competition has further narrowed the scope for political action by indigenous groups. As the dominating party in a predominantly mestizo society, the PRI embodies above all the values and aspirations of the Mexican mestizos. At the same time, the monopolization of political activities by a single party has effectively blocked the rise of parties more closely associated with specific sectorial or ethnic interests.

Since the beginning of the seventies, however, indigenous communities have started to organize themselves in an attempt to defend their common economic and political interests more effectively. At the federal level, these organizations sometimes receive official patronage, like the National Council for the Indigenous Peoples of Mexico, which is funded by the National Indigenous Institute. But it is at the regional level that the efforts to create organizations of self-defense have had the greatest political impact. Most of these organizations have been the product of unresolved land disputes. In states like Oaxaca, Hidalgo and Chiapas, indigenous peoples frustrated by endless administrative proceedings and disillusioned with the unfulfilled promises made by the PRI to tackle chronic land problems, decided to set up rural organizations to support their land demands and to politically advance their cause. These political associations organize protests, marches and demonstrations, and in some cases resort to illegal invasions of lands to achieve their goals. ${ }^{55}$ They usually meet with fierce opposition from the local economic and political elites determined to prevent any changes which could jeopardize their interests. Organizations like the Organización Campesina Emiliano Zapata in Chiapas or the Unión Regional de Ejidos y Comunidades de la Huasteca Hidualgense in Hidalgo have constantly been hampered in their activities by local political bosses and government officials. The means used to sabotage the work of indigenous associations include the refusal to register them as legal agrarian organizations, the creation of internal divisions by purchasing the support of alternative leaders and the intimidation, arbitrary emprisonment and assassination of their leaders as well as of ordinary members. ${ }^{56}$

See the report of Amnesty International, Mexico. Human Rights in Rural Areas, London 1986, which states numerous cases of human rights violations committed against the members of independent peasant organizations in the rural states of Oaxaca and Chiapas in the 1970s and early 1980 s. 


\section{Recent changes in Mexican law and their impact on the indigenous groups}

\section{The constitutional recognition of Mexico's pluriethnic character}

Shortly after taking office in December 1988, the newly elected President Salinas de Gortari created the National Commission of Justice for the Indigenous Peoples (Comisión Nacional de Justicia para los Pueblos Indígenas de México) as a consultative body within the National Indigenous Institute. Its first mission was the elaboration of a proposal for a constitutional amendment establishing the legal basis for a more effective protection of Mexico's indigenous groups. After consulting extensively with the indigenous groups, human rights organizations, political leaders and various private and public bodies the Commission proposed to the President a constitutional amendment which explicitly recognized the pluriethnic composition of the Mexican nation by referring to the existence of the indigenous peoples and ordered the Federation, the States and the municipalities to enact within the limits of their respective competences the laws necessary for the protection of the languages, cultures, customs and specific forms of social organization of the indigenous communities. The corresponding provisions were to be considered as rules of public order and social interest (orden público y' interés social). Indians should be granted an effective access to jurisdiction, and in proceedings before the federal and local courts their legal practices and customs would have to be taken into account.

This proposal served as a basis to the constitutional amendment which was submitted to the Chamber of Representatives, the Lower House of the Mexican Parliament ${ }^{57}$, by President Salinas de Gortari on December 7, 1990. The amendment was finally adopted, after intensive debate in the commissions, by a majority of representatives from the governing PRI and the leftist Party of Democratic Revolution (Partido de la Revolución Democrática), with most of the members of the nationalist right-wing PAN party (Partido Acción Nacional) abstaining. ${ }^{58}$ After receiving the approval of the Senate and the state legislatures it entered into force on January 28, 1992. The amendment reads as follows:

"The Mexican nation has a pluriethnic composition originally based on its indigenous peoples. The law shall protect and promote the development of their languages, cultures, uses, customs, resources and specific forms of social organization, guaranteeing to their individual members an effective access to the jurisdiction of the State. In the agrarian suits and proceedings in which those members are a party, their legal practices and customs shall be taken into account in the terms established by the law."

The Mexican Parliament, the Congress (Congreso General), consists of two chambers, the Chamber of Representatives representing the Mexican nation, and the Senate representing the States. Constitutional reforms have to be adopted by a two-thirds-majority in each chamber and by a majority of the state legislatures, see Article 135 of the Constitution of 1917.

Madrazo, supra note 2, pp. $29 / 30$. 
At the same time, an amendment to Article 27, para. VII of the Constitution was adopted according to which "The Law shall protect the integrity of the lands of the indigenous peoples" (see 3 below).

The amendment to Article 4 of the Constitution represents a fundamental shift in the of ficial Mexican policy toward the indigenous peoples, since it officially acknowledges that Mexico is a pluriethnic and pluricultural nation, thus abandoning the traditional goal of creating an ethnically homogenous society based on the model of the mestizo culture. It is a compromise between the defenders of the traditional doctrine of legal equality who argued that Indians enjoyed the same basic rights under the Mexican Constitution as everybody else and therefore did not need any special legal protection, and their opponents who wanted to go further and advocated some sort of self-government for the indigenous peoples within special Indian areas recognized by the Constitution. ${ }^{59}$

The practical value of Article 4 of the Constitution will largely depend on the implementing legislation. According to Article 4, "the law" ("la ley") shall protect and promote the Indian languages, cultures, uses, customs and resources and set out in detail the Indian legal practices to be taken into account in agrarian suits. One of the most important tasks of the legislation will be to establish a precise and legally binding definition of the term "Indian". In the past, the decision whether to recognize certain groups or individuals as Indian or not did not follow a coherent pattern, depending in most cases on considerations of administrative expediency and the political requirements of the moment. If the definition of the term "Indian" were to be left to the discretion of the administration and the courts, this would severely reduce the scope and the effectiveness of any future protective legislation and turn Article 4 into a merely aspirational clause without any real meaning. Up to now, however, few, if any implementing legislation seems to have been enacted on the basis of Article 4, as a short survey of recent legislative and administrative activity in the policy areas traditionally most important to Indian interests will show.

\section{Agrarian law}

As has already been mentioned, most indigenous groups are living in rural areas. These communities are dependent on the exploitation of their lands in order to grow the agricultural products necessary for their subsistence. ${ }^{60}$ Moreover, Indians belong to a society 
that draws its social and religious, as well as economic, life from the land. ${ }^{61}$ They traditionally regard the land as collective nontransferable property of the community, not as a merchandise or liquid capital, a view that tends to collide with the concept of private land ownership which was incorporated into the national legislation as a result of the economic liberalism of the nineteenth century. ${ }^{62}$ The problem of land distribution has therefore been of central importance to Mexico's indigenous groups. Most human rights violations committed against Mexican Indians in recent times have occurred as a result of the victims' activities in organizations engaged in land disputes with landowners and local and state authorities. $^{63}$

The origins of Mexico's agricultural land system date back to the 1910 revolution, which was in part provoked by the grossly unequal land distribution and the resulting plight of the landless rural poor, among them many indigenous groups. In response to the demands for a fair and equitable distribution of land, the Constitutional Congress created in 1917 Article 27 of the Constitution, which was to form the legal basis for any kind of property rights in Mexico, whether public or private. Article 27 established the foundation for a new body of administrative law involving rural questions, now known in Mexico as "Agrarian Law" ${ }^{64}$. Article 27 compelled the government to give land to any group of peasants who asked for it. In particular, Article 27 para. VII conferred upon the so-called "centers of population" (nucleos de poblacion) which, by law or in fact, possess communal statutes, the legal capacity to enjoy common possession of the lands, forests and waters belonging to them or which have been or may be restored to them. In addition, Article 27 para. X provided that those centers of population which lack communal lands - the so-called ejidos - or which are unable to have them restored to them due to the lack of titles, impossibility of identification, or because they had been legally transferred, were to be granted sufficient lands and waters to constitute new ejidos, in accordance with the needs of the population (Art. 27, para. X).

Under Article 27, indigenous communities thus had a constitutional right to obtain lands from the government either by means of restitution - if they could prove that the land they claimed had been legally theirs in the past - or by constitution of new ejidos in cases of lack of title or impossibility of identification. In principle, no individual property was

Weil, supra note 6, p. 90. This is a common feature of most indigenous peoples, see Alexandra Kersey, The Novanut Agreement: a Model for preserving Indigenous Rights, 11 Arizona Journal

62 Rudolfo Stavenhagen, Derecho consuetudinario indígena en America Latina, in: Rudolfo of International and Comparative Law (Fall 1994), p. 446. Stavenhagen / Diego Iturralde, Entre la ley y la costumbre, México 1990, pp. 39/40.

63 Nahmad, supra note 26, pp. 308/309; Amnesty International, supra note 56, p. 2.

64

Ruben Valdez Abascal, Reformas al Articulo 27 de la Constitución Politica de los Estados Unidos Mexicanos en Materia Agraria, in: Instituto de Investigaciones Jurídicas, supra note 2, p. 58. 
allowed within the communal lands, which remained inalienable and protected by federal laws. The application of Article 27, however, has given rise to numerous practical problems and caused frustration in many Indian communities over the inadequacies of Mexico's land reform program. Not all campesinos who have the legal right to a piece of land, and who had already applied for the said lands in the past, have received them. Moreover, although ejidos in theory are communal lands for collective use of a rural community, numerous ejidos have been appropriated by individual ejidarios, thus creating severe tension within the rural communities. In several cases, the Board of Directors which is legally competent to control the ejido has abused its powers to allocate the best lots to individual owners. Finally, the administrative process established by Agrarian Law for the granting of lands to indigenous communities is quite long and bureaucratic, taking some 15 years to be completed. Tired of waiting to obtain their lands and discouraged by unanswered petitions, arbitrary acts of landowners and corruption, indigenous groups in several Mexican states have increasingly turned to violent means and invaded lands in the vicinity physically possessed or legally owned by others. This strategy has provoked violent reactions from landowners and public authorities and of ten resulted in the detention, criminal prosecution or even killing of Indian leaders, most notably in the states of Oaxaca, Chiapas and Hidalgo (see $\mathrm{V}$ below).

In 1992, the Mexican government implemented a dramatic change in its seventy-five-year old system of land ownership by amending its Constitution and enacting a new law on the subject (Ley Agraria) in order to prepare the country for the North America Free Trade Agreement (NAFTA) and to modernize the national economy. The legislative reforms introduced in February 1992 allow individuals and companies to have full ownership rights over what were formerly communally owned lands (ejidos) and permits the formation of joint ventures between individuals in ejidos (ejidarios) and private investors or other ejidarios as well as foreign direct investment in the ejido sector. Art. 27, para. VII of the Constitution was revised. It now reads as follows: "The legal personality of the ejidal and communal centers of population is recognized, and their ownership of land, for purposes of human settlement as well as for the purpose of productive activities, is protected. The law shall protect the integrity of the lands of the indigenous peoples." At the same time, Art. 27, para. X was abolished. As a practical matter, the constitutional right to be granted land by the state has thus been eliminated. The Mexican government believes that further redistribution will only result in lower productivity, greater impoverishment and increased insecurity over property rights. ${ }^{65}$ In addition, a new set of courts, the federal agrarian courts (tribunales federales agrarios) were created to resolve the disputes related to land tenency by ejidos and local communities. Article 164 of the new Agrarian Law (Ley agraria)

Guillermo Marrero / Douglas J. Renert, The Long and Winding Road: An Overview of Legislative Reform on Mexico's Road to a Global Economy, Southwestern Joumal of Law and Trade in the Americas, (Winter 1994), pp. 90/91. 
explicitly provides that in law suits which concern Indian lands the customs and uses of each of the affected indigenous groups have to be taken into account, as long as they do not contradict the law or infringe the rights of third parties. The government has also set up a national program designed to help the indigenous population with the registration of their land titles (Programa de Certificación de Derechos Ejidales y Titulación de Solares Urbanos - PROCEDE). ${ }^{66}$ However, it has to be feared that the indigenous groups are ill prepared to take advantage of the new legal provisions and could become victims of the liberal rules governing external investment in communal lands. It is therefore not surprising that the Indian rebels in Chiapas have claimed, inter alia, the annulment of the recent amendments of Article 27 (see $\mathrm{V}$ below). In this situation, the adoption of legislation which implements the protection clause of Article 27 para. VII and regulates the right of the indigenous groups to use and distribute their land is an urgent priority. Up to now, however, such a statute has not been adopted. The legislator merely included some provisions of a purely procedural nature into the new Agrarian Law which oblige the tribunals to take into account Indian usages and customs when they decide cases involving Indian lands and to provide interpreters to the Indian party when necessary. ${ }^{67}$

\section{Administration of justice and access to jurisdiction}

At the beginning of the 1990's, the government of President Salinas de Gortari initiated farreaching reforms of Mexican criminal law. Articles 18 to 22 of the Constitution were modified to expand the constitutional rights of accused persons in criminal proceedings, including the investigations and interrogatories conducted by the police. Federal and State codes of penal procedure as well as penal codes have also been changed to put them in symmetry with the new constitutional provisions. Several changes were made with regard to the special needs of Indians in criminal proceedings. Every person who does not sufficiently speak or understand Castillian Spanish, regardless whether he is involved in the criminal proceedings as suspect, as victim or as a witness, has the right to be assisted by an interpreter from the very start of the proceedings. ${ }^{68}$ During the criminal investigation, the judge has to explore, inter alia, whether the accused belongs to an indigenous group and what the characteristics and practices of this group eventually are. ${ }^{69}$ So far there is little information as to the implementation of these rules in practice. Given the formidable variety of Indian languages, the availability of interpreters in criminal proceedings may raise some practical problems. On the other hand, the respect of Indian customs would

66

67

68

69

CERD/C/260/Add. 1, para. 84.

Article 164 of the Agrarian law (Ley Agraria).

Article 128 Federal Code on Penal Procedure, Articles 183, 269 and 285bis; Code on Penal Procedure of the Federal District.

Article 196bis of the Code of Penal Procedure of the Federal District. 
seem to require a substantial knowledge of Indian practice which judges, like most public officials, are unlikely to possess. The same observations apply to the proceedings in agrarian law suits where similar rules have been created by the new Agrarian Law (see 2 above). In its response to the demands presented by the Indian rebels in Chiapas, the Mexican government originally asserted that it would promote amendments at the state level in order to create judicial districts coinciding geographically with indigenous communites. These amendments would provide that the judges in these districts may be Indians themselves or mestizo professionals respected in indigenous communities, be familiar with Mexico's positive law and be willing to always take into consideration Indian usages and customs in adjudicating their controversies. ${ }^{70}$ This commitment has not yet been transformed into legislation.

\section{Education and culture}

The "policy of assimilation" which prevailed in the first decades after the Mexican revolution has increasingly been abandoned since the beginning of the seventies in favour of the concept of a bilingual-bicultural education. The amended Article 4 of the Constitution explicitly provides for the protection and promotion of Indian languages and cultures. In the context of its Education Modernization Program the Mexican government has tried to secure a better access of the Indian population to all levels of public education and to improve the material conditions for a bilingual-bicultural education, namely by increasing the number of bilingual teachers working in indigenous areas. ${ }^{71}$ In addition, text books have been published in various indigenous languages in recent years. ${ }^{72}$ However, the reversal in education was the result of a gradual change in administrative policy and has not been transformed into binding legal rules. As yet there exists no specific legislation which would give the principle of bilingual-bicultural education a legal status and fix the guiding principles for its implementation in schools and universities.

\section{Federal agencies for the protection of indigenous rights}

At the federal level, several bodies have been established over the last years in order to improve the institutional framework for an effective promotion and protection of indigenous rights. The National Commission of Justice for the Indigenous Peoples, which elaborated the proposal leading to the reform of Article 4 of the Constitution has already been 
mentioned. Another body was created by presidential decision in January 1994, shortly after the outbreak of the Indian rebellion in Chiapas. The National Commission of Development and Social Justice for the Indigenous Peoples shall define the administrative policies needed for a better development and the improvement of living conditions of the indigenous peoples and coordinate their implementation. The most important government ministries and federal agencies are represented in the Commission. ${ }^{73}$ The relationship between this Commission and the National Indigenous Institute as the official organ to design indigenous policy is not quite clear.

Another development with a potential impact on the protection of indigenous rights has been the creation of human rights commission at the federal and state levels. The National Commission of Human Rights (CNDH) was established by the President of Mexico in June 1990. Furthermore, based on an amendment to Article 102 of the Constitution, it is now obligatory for every state in the Republic of Mexico, and for the Federal District, to create state commissions to guarantee the respect and promotion of human rights within their respective jurisdictions The National Commission of Human Rights is competent to investigate cases of alleged human rights violations and to recommend the appropriate remedial action to the government. ${ }^{74}$ Over the last few years, the Commission has investigated a considerable number of complaints concerning human rights violations against members of indigenous communities. ${ }^{75}$ However, it has attracted criticism from human rights organizations for its close links with the President (who appoints the director of the Commission) and its alleged timidity in handling politically sensitive cases in which the higher levels of the federal government are involved. ${ }^{76}$

\section{The persistent disregard for indigenous rights in rural Mexico: the case of Chiapas}

All efforts to improve the constitutional and legal protection of indigenous groups, as laudable as they may be in theory, will be of little use as long as the legal rules created for this purpose are not enforced by the competent authorities and powerful interest groups are allowed to violate indigenous rights with impunity. In the past, Mexico's indigenous communities, especially those living in the countryside, have been the targets of constant

73

74

See Article 102 B of the reformed Mexican Constitution, and Jorge Carpizo, Analisis del Articulo 102, Apartado B, de la Constitución, in: Instituto de Investigaciones Jurídicas, supra note 2, pp. 75 to 91 .

75

76 105.

Vargas, supra note 3, p. 37. 
human rights abuses, consisting mainly in the illegal dispossession of Indian lands and the brutal repression of the protest movements it provoked. Nowhere has the traditional disregard for Indian rights been more deeply rooted than in the state of Chiapas, where the appalling conditions of oppression and injustice that had been so successfully imposed for decades on the poorest people of the state finally attracted world-wide attention with the eruption of the armed rebellion launched by the Zapatista National Liberation Army (Ejército Zapatista de Liberación - EZLN) on January 1, 1994.

Chiapas has an indigenous population of almost one million, most of them speaking a maya dialect. In terms of natural resources, Chiapas is one of the richest states in Mexico. It is endowed with fertile farmlands, pastures, and forests, and supplies large amounts of oil, cocoa, coffee, beef and sugar to the rest of the country. It ist also host to a major hydroelectric project that provides electric power to a large portion of Mexico, and the site of intense geological explorations conducted by PEMES, the federal parastate oil monopoly. ${ }^{77}$ At the same time, Chiapas is also one of the poorest states of Mexico, where two million residents have less than elementary school education and the illiteracy rate reaches 30 percent. At least one 1.1 million citizens live in communities without electricity, 1.3 million live in communities without running water and 1.6 million in houses with dirt floors. ${ }^{78}$ Almost two thirds of the working population do not even earn the minimum wage. ${ }^{79}$ In short, Chiapas is a rich land of poor people. ${ }^{80}$ Despite the modernization policies of successive state and federal governments it is the least developed and most backward of all Mexican states. When he took office in 1988, President Salinas de Gortari, following the example of his predecessor Miguel de la Madrid ${ }^{81}$, had targeted Chiapas as a major recipient of his anti-poverty campaign known as Mexico's National Solidarity program. The state received approximately $\$ 727$ million to finance 8,869 public works ranging from gravel roads to basketball courts. The program, like others before it, was hampered by mismanagement and corruption and did not really change anything in Chiapas except to put more money into the pockets of local politicians and contractors. Although the corruptive practices were conducted in an open and regular manner and with active participation of prominent members of the state government, the federal government decided to turn a blind

77

78

79

80

81

In his campaign for the presidency in 1982, Salinas' predecessor Miguel de la Madrid had promised a major development program for Chiapas. The 300 million-dollar plan Chiapas which was finally unveiled in January 1983 concentrated on the construction of irrigation works and roads outside the so-called "politically sensitive areas" of the Central Highlands and the Palenque region and provided the cover for a new military road along the border to Guatemala, see Ben jamin, supra note 79, pp. 241/242. 
eye on the abuse of federal funds. The Governor of the State, González Garrido, was even promoted to the post of Secretary of the Interior (Secretario de Gobernación), the most powerful post in the Mexican cabinet, although a confidential government document had accused him of having ordered the arrest of three Solidarity officials on charges of fraud, embezzlement and corruption after they refused to let him administer federal anti-poverty funds. ${ }^{82}$

Land disputes have played a central role in the recent political history of Chiapas. A powerful coalition of wealthy landowners and public officials has been engaged for decades in dispossessing the Indians in Chiapas of their fertile lands by the most violent and arbitrary means. Several decades after the Mexican revolution the promise of a comprehensive agrarian reform contained in the Constitution of 1917 still remained unfulfilled in many parts of the state. Indian groups were increasingly frustrated with their attempts to get their communal lands restored to them or to be granted new lands by the government under Article 27 of the Constitution. Before 1994, Chiapas accounted for almost a third of Mexico's backlog of cases which should have been decided by the land rights courts, although its population represented a mere 4 percent of the total Mexican population. There were still almost 4,000 Chiapaneco cases pending and a further 164 presidential decisions which had yet to be implemented. ${ }^{83}$ Government resolutions favorable to indigenous communities and ejidos were in many cases suspended due to injunctions requested by landowners while they appealed the decision. ${ }^{84}$

The situation was further worsened by the process of ganaderizacion, i.e. the expansion of pasture for cattles at the expense of cropland, which had reached an unprecedented dimension since the 1970s. Cattlemen converted lands formerly rented or share-cropped by corn farmers into pastures, rented or simply invaded ejido lands, and expanded into wooded or jungle areas causing destructive deforestation and soil erosion. Following peasant farmers into the Lacandón forest on new government-built roads, cattlement purchased or stole the cleared pots to form large ranches. As cattle herds expanded and pastures increased in Chiapas, land erosion and exhaustion accelerated and the production of corn and other basic grains stagnated. The lack of irrigated and arable land reduced many Indians to the status of day laborers on one of the large fincas of white or mestizo landowners, often living in huts and receiving less than the minimum wage. Chronic alcoholism, malnutrition, and diseases such as tuberculosis, typhus and intestinal parasites plagued Indian communities. According to inofficial estimates, nine of ten Indian children were undernourished. ${ }^{85}$

82

Vargas, supra note 3, p. 10. A few days after the outbreak of the Chiapas rebellion, however, Gonzáles Garrido was forced to submit his resignation.

83 Mexico \& NAFTA Report, 11 May 1995, p. 5; Vargas, supra note 3, p. 9.

84 Benjamin, supra note 79, pp. 232/233.

85 Id. at p. 230. 
Since the beginning of the 1970s, an increasing number of indigenous groups responded to the mounting economic hardship by invading private property of wealthy landowners and cattle ranchers and by staging demonstrations and marches to attract public attention to their miserable situation. This triggered violent reactions of cattle and plantation landowners, who appealed to the army or to paramilitary forces to force the Indians off their lands and pursue their leaders. Because most Indian actions were carried out in an unorganized manner in small and often isolated localities, state and federal authorities were able to employ the most brutal kind of repression to preserve peace and order and to protect private property. ${ }^{86}$ Land invasions, violent expulsions and confrontations with authorities multiplied during the following decade throughout the countryside. The politicization and organization of the Indian protest movement was intensified by the First Indigenous Congress in Chiapas, organized by Bishop Samuel Ruiz in San Cristóbal de las Casas in 1974. At the beginning of 1980s, efforts to unify and coordinate the agrarian struggle in Chiapas were made which led to the establishment of state-wide peasant organizations like the Unión of Ejidal Unions and Marginalized Groups of Chiapas and the Emiliano Zapata Peasant Organization. ${ }^{87}$ The activities of the independent peasant organizations increasingly undermined the influence the governing PRI and its rural arm, the National Peasant Confederation (CNC), enjoyed among the rural population. ${ }^{88}$ As a consequence, ${ }^{-}$their leaders and activists were frequently the victims of brutal repression measures by CNC members, coffee growers, ranchers and their paramilitary forces, as well as by state and federal authorities, including harassment, intimidation, death threats, summary executions, disappearances and torture. ${ }^{89}$ At the same time, partly in reaction to the mass exodus of Guatemalan refugees fleeing the murderous counterinsurgency campaign of General Rios Montt and to growing fears that Central American guerilla movements could take advantage of the situation to spread the germ of social revolution in Chiapas, the Mexican government increased the number of army units in the state in order to secure its southern border and squash dissident popular movements. During much of the 1980s, Chiapas was living under a state of siege. ${ }^{90}$ Not surprisingly, the PRI chose an army general as governor of the state in 1982. Although governor Castellanos Dominguez recognized the gross unequalities in wealth distribution as one of the major causes of the state's continuing crisis ${ }^{91}$, his government in practice continued to rely on purely repressive policies to solve the "agrarian problem". In a study published in 1987 by the Mexican Academy of Human

86

87

88

90 Ben jamin, supra note 79, p. 237.

91 Id. at p. 239.

Id. at p. 229.

Id. at p. 236.

Vargas, supra note 3 , pp. $48 / 49$.

These human rights violations have been documented by Amnesty International in its report on human rights in rural areas, supra note 56, pp. 10 to 88 . 
Rights the Castellanos administration was characterized as the most repressive and one of the most corrupt state governments in Mexico. ${ }^{92}$ Under his successor González Garrido, the escalation of violent acts committed by ranchers and public authorities against members of independent peasant organizations in response to land invasions and protest demonstrations continued unabated.

Although there had been unmistakable signs of a deepening social and political crisis in Chiapas for some time, the outbreak of the Chiapas rebellion on January 1, 1994 took Mexico's government, and the world, by surprise. The federal government at first refused to admit that it was facing a guerilla movement and said that the rebels were ordinary criminals who would be treated as such. After the rebels had enjoyed almost complete control of several towns in Chiapas during the first 24 hours of the rebellion, the Mexican Army launched a massive military attack against the retreating revels, appearing to bomb anything that moved, including media vehicles, along the road. According to jeurnalists and human rights activists witnessing the events in Chiapas, the Army committed numerous human rights violations during its bloody of fensive against the Indian rebel movement, which had claimed the uprising in the name of the previously unknown Zapatista Liberation Army and declared war on the federal government in their first statement a few hours after the start of the rebellion. The alleged human rights abuses included the bombing of inhabited towns, unconstitutional searches of homes, illegal and arbitrary detentions, the homicide of civilians and summary executions. In early June, the National Commission of Human Rights published a report on the human rights violations committed as a result of the Chiapas conflict. In the report, the Commission explicitly acknowledged that members of the Army as well as public officials of the Attorney General's Office had "physically mistreated" several persons and produced false charges against them, but stopped short of demanding a criminal investigation of their misconduct.

In mid-January President Salinas, probably reacting to mounting international criticism, reversed his initial policy which aimed at a military solution to the conflict and offered a cease-fire and an amnesty to the rebels. He agreed to negotiations and picked the former mayor of Mexico City, Camacho Solis, as Peace commissioner for Chiapas. The peace talks with the rebels which began on February 22 under the mediation of the Bishop of San Cristóbal, Samuel Ruíz, were concluded on March 2 with the publication of a document entitled "Demands and Engagements to Achieve a Dignified Peace in Chiapas" that included 34 specific demands by the Zapatistas and the replies from the government negotiator. 
The political demands of the EZLN included the resignation of the Mexican President and other "State executives" and the immediate constitution of a transition government. Among the legal measures advanced by the Zapatistas the most significant were the revision of the text of the North American Free Trade Agreement to take into account the needs and interests of the indigenous peoples, the repeal of the Penal Code of Chiapas which in the past had been used to repress Indian protest movements, the annulment of the recent changes to Article 27 of the Constitution (see IV.2 above) and the recognition of the right of indigenous groups to administer their own system of justice without any external interference. The EZLN also put forward a certain number of socio-economic demands concerning the improvement of public infrastructure in the indigenous communities, the fight against malnutrition and illiteracy, the creation of dignified jobs with a just salary and specific measures to address the urgent needs of indigenous women in that part of Mexico. $^{94}$

No demand advanced by the Zapatistas was completely rejected by the Peace Commissioner. He simply noted that the political demands calling for the resignation of the President and for truly free elections involved national issues and thus were not subject to negotiations at a regional level. ${ }^{95}$ As to the other demands, the government asserted, inter alia, its readiness to promote constitutional amendments to create judicial districts coinciding geographically with indigenous communities, to enact a General Act on the Rights of Indigenous Communities which would provide for an effective protection of their land rights and to establish a District Attorney's office for the Defense of Indigenous Peoples in penal and labor proceedings. ${ }^{96}$

The document met with considerable resistance from hardliners within the PRI and from ranchers and merchants in Chiapas who claimed that it virtually amounted to a unilateral surrender by the government. ${ }^{97}$ Whatever the original prospects for a political solution to the conflict along the compromise lines set out in the document may have been they clearly deteriorated with the assassination of the PRI presidential candidate, Luis Donaldo Colosio, in late March. Shortly after talks had resumed in May, Camacho Solis resigned as a Peace Commissioner because of a political clash with the new presidential candidate appointed by the PRI to succeed Colosio, Ernesto Zedillo Ponce de Léon. His Successor, the former head of the National Commission of Human Rights, did not achieve any substantial progress until the negotiations broke off again in October 1994.

94

95

96

97 
After taking office in December 1994, the new President Zedillo Ponce de Léon at first seemed to favour further negotiations with the Zapatistas, before adopting a harder line in early February by issuing warrants for the arrest of the leaders of the EZLN and ordering the army to recover part of the territories controlled by the rebels. This new policy, however, was soon tempered with a series of conciliatory moves, culminating in the Law for Dialogue, Conciliation and Dignified Peace in Chiapas which was adopted by the Federal Congress in March. The law provided, among other things, for the suspension of the arrest orders issued against the Zapatista leaders once the conciliatory talks were resumed, and for the necessary measures to guarantee the free transit and personal safety of the EZLN's negotiators. At the same time, the federal and the state government offered guarantees and aid for the return to their place of origin of the Indians and campesinos displaced by the conflict.

The talks finally resumed in late April, but so far have not produced any substantial results. The government has offered to withdraw the army from the areas where the Zapatistas are strongest in Chiapas if the EZLN hands over its weapons, turns into a political party and marshalls its members in three pre-arranged security zones in Chiapas, an offer that was rejected by the Zapatistas as a call for their unconditional surrender. ${ }^{98}$ On the other hand, the demands for a profound change in the political and economic structure in Chiapas and in Mexico at large, which had dominated the discussions between the EZLN and the government negotiator in February 1994, seem to have disappeared from the agenda. Given the negative reactions the document negotiated by Camacho Solis had produced among the urban middle classes and landowners as well as in some sectors of the PRI, it seems unlikely that the Mexican government will enter any such far-reaching agreement again in the foreseeable furture. Therefore it is more realistic to assume that the federal government will try once more to improve things by pouring money into the inf rastructure and the economy of the state, despite evidence that this approach has failed to produce any lasting change in the past.

\section{Conclusion}

In conclusion, one has to say that Mexico's indigenous policies have largely failed to provide its Indian communities with an adequate protection from discrimination and exploitation by their fellow criollo and mestizo citizens. On the contrary, Mexico's indigenous peoples have been pushed to the very margins of society ever since the Spaniards conquered and destroyed the Aztec empire, a trend which remained virtually unchanged throughout the different periods of Mexican history, beginning with the policy of "benevolent guardianship" during colonial rule and ending with the of ficial recognition of

98

Mexico \& NAFTA Report, 11 May 1995, p. 4. 
the pluriethnic character of the Mexican nation in 1992. Despite recent constitutional and legal changes acknowledging the special needs and rights of indigenous groups in the country, Mexican Indians continue to be the victims of a silent but pervasive discrimination, a discrimination which is not merely the consequence of the gross unequalities in economic opportunities existing in present-day Mexico, but is at least partly based on racial considerations.

The amendment to Article 4 of the Mexican Constitution, which recognizes for the first time specific rights of the indigenous communities as an essential component of the "pluricultural" Mexican nation, constitutes a step in the right direction. Without the corresponding federal statute, however, which implements the principles enunciated in Article 4 at the administrative and judicial levels, this provision will be of little practical significance. In order to fulfill the constitutional mandate contained in the revised Article 27 of the Constitution - according to which the law shall protect the integrity of the territories of the indigenous groups - specific legislation is needed to recognize the collective ownership of the indigenous communities and to regulate the distribution and the use of their lands in detail. It is desirable to go even further and to confer upon the various indigenous groups a certain degree of political autonomy which would allow them to decide all internal and local affairs according to their customs and practices. For this purpose, special Indian areas would have to be created, whose boundaries should coincide with those of the ancestral lands of the local indigenous peoples wherever possible. The administrative status of these areas would be that of an autonomous region, below the federal and the state level, but above the municipal level. The map of the electoral and judicial districts at the federal as well as the state level should be redrawn in accordance with the boundaries of the newly established Indian territories so as to allow for an effective representation of Indians in the political process and a proper administration of justice taking into account Indian usages and customs. A modification of the boundaries of Indian areas would require the consent of the indigenous communities concerned. Constitutional changes affecting Indian autonomy rights would have to be approved by a qualified majority of the indigenous communities in the country and in the the state respectively. Autonomy rights of this kind, while falling short of rights to secession and independence, would permit the indigenous groups to develop local policies in accordance with their needs and wishes and to fully participate, through their own representatives, in any decision-making process which may affect them. They appear therefore as a viable and necessary means to preserve the culture and status of Mexico's Indians as distinct peoples. ${ }^{99}$

99

The Draft Declaration on Indigenous Rights recently formulated by the United Nations Working Group on Indigenous Peoples explicitly recognizes the indigenous right of self-determination, see Report of the Working Group on Indigenous Populations on its Eleventh Session, U.N. Commission on Human Rights, Sub-Commission on Prevention of Discrimination and Protection of Minorities, 45 ${ }^{\text {th }}$ Session, Annex I, at p. 50, UN Doc. E/CN.4/Sub 2/1993/29 (1993). Article 31 of the Draft Declaration reads as follows: "Indigenous peoples, as a specific form of exercising their 
Apart from the enactment of the implementing legislation provided for in Articles 4 and 27 of the Constitution and the establishment of a sufficient territorial base for some sort of Indian self-government, the most urgent problem that needs to be addressed is the constant disregard for the already existing legislation in many parts of the country. In many instances, the discrimination against indigenous groups is not primarily due to the lack of legal rules - the Indians enjoy after all the same fundamental rights protected under the Constitution as all other Mexicans - but to the fact that economic interest groups and local politicians are frequently allowed to pursue their abusive practices at the detriment of indigenous groups with impunity. What has to be changed is the intimate nexus between political power and economic interests which keep certain sectors of the population permanently at the margins of society. ${ }^{100}$ This will be a difficult task because the incumbent regime is riddled with functionaries who, with or without authorization from above, are willing to resort to practices which are antithetical to the imperatives of an impartial and democratic administration. Twelve years of rule by "modernizing technocrats" under the presidencies of Miguel de la Madrid and Salinas de Gortari did not systematically change the arbitrary ways of an inefficient and often corrupt bureaucracy. ${ }^{101}$ At an even more general level, a profound reform of the present political system seems necessary before the present conditions of repression and injustice can be successfully eliminated. In many cases, it is the local branch of the governing PRI party, from the Governor of the State to the local police officer, which is engaged in repressive activities against indigenous communities. As past experiences have shown, the PRI-dominated federal government can hardly be expected to respond vigorously to human rights violations committed by PRI members at the state and municipal levels. In this regard, the events in Chiapas are a powerful testament to the untouchability of PRI-fiefdoms in some of Mexico's isolated rural areas. ${ }^{102}$ The impenetrable nexus of economic and political power which has characterized the Mexican political system in the post-revolutionary era has its roots in the firmly cemented one-party rule by the PRI and the absence of any real separation of powers. Only if the PRI loses its iron hold on national power and one-party rule is replaced by a truly competitive, politically balanced multi-party system will it be possible for an independent judiciary and a strong political opposition to act as an effective check on the worst human rights abuses. At the same time an effective multi-party competition would facilitate the

right to self-determination, have the right to autonomy or self-government in matters relating to their internal and local affairs, including culture, religion, education, information, media, health, housing, imployment, social welfare, economic activities, land and resources management, environment and entry by non-members, as well as ways and means for financing these autonomous functions." The Draft Declaration has not yet been approved by the United Nations General 100 Assembly.

101 Wayne A. Cornelius, Mexico's Delayed Democratization, Foreign Policy 95 (Summer 1994), 102 p. 68.

Id. at p. 63 . 
creation of a much-needed new social policy to protect the weakest sectors of the Mexican population, including the indigenous groups, against the mounting hardships from Mexico's recent liberalizing economic policies. 


\title{
ABSTRACTS
}

\section{The Constitutions of Caribbean Commonwealth States}

\author{
By Karl Leuteritz
}

The Caribbean countries have not drawn much attention to their constitutional systems, yet. Independence from the respective colonial countries has not fully removed the legal ties with and the constitutional relationship to the European countries. The article introduces the twelve independent countries which are part of the British Commonwealth and distinguishes them from their neighbour countries.

The constitutions of eleven of the twelve Caribbean Commonwealth countries are very similar. Ten of these constitutions are still based on the original independence constitution, most of them with the British Queen as Head of State. And even in the case of Trinidad \& Tobago only few constitutional changes followed the transformation into a republic in 1976. Thus these eleven constitutions following the original Marlborough House Type constitution are surveyed together regarding their constitutional history, their bills of rights, and their legislative, executive and judicial structures. Special and separate attention is given to the constitutional structures of Guyana which broke with the tradition of the independence constitution in 1970, proclaiming a co-operative republic and substituting it with a new constitution in 1980.

The constitutions of the Caribbean Commonwealth states show close similarities to the British model and have - with few exceptions - resulted in the development of democratic structures. As the constitutional structures in these countries are regarded by the respective population as its "own" structures, the author concludes that the development of democratic societal structures will also prove to be solid and effective in the future.

\section{The Chiapas Rebellion and the Failure of Mexico's Indigenous Policy}

\section{By Rainer Grote}

Mexico's indigenous peoples have been pushed to the very margins of society ever since the Spaniards conquered and destroyed the Aztec empire. After the policy of benevolent guardianship pursued by the Spanish Crown during colonial rule and the adoption of the doctrine of legal equality as guiding principle of of ficial Mexican attitudes toward Indians 
in the post-independence period, the government's indigenous policy since the Revolution of 1910/17 has been dominated by the concept of mestizaje, which views the assimilation of the Indian into the mestizo society as a necessary prerequisite for the achievement of national unity. The government's assimilation policies, however, have subsequently failed to produce any lasting change in the miserable economic and social conditions in which the overwhelming majority of Mexico's indigenous groups have been living for centuries. It was only in 1922 that the pluriethnic composition of the Mexican nation and the distinct character of the indigenous peoples have been officially recognized. Nevertheless, most of the implementing legislation which would give a full meaning to this principle and provide the Indians with a sufficient measure of protection for their economic and political rights has yet to be enacted. Moreover, the Chiapas rebellion has drawn international attention to the fact that the central government for decades has been turning a blind eye on the constant disregard and massive violation of Indian rights by a powerful coalition of local interest groups and corrupt politicians. The success of legal efforts to end discrimination against Indians is thus in no small measure dependent on the success of political reform in general, which would replace the long lasting one-party rule in Mexico with a truly competitive, politically balanced multi-party system based on the effective implementation of the principle of separation of powers.

\section{Land-law and Landholding in Surinam}

\section{By Harold F. Munneke}

The former Dutch colony Surinam has known, from 1869 on, a Civil Code providing for legal titles, which should have been applicable to landholding.

However, special regulations, setting aside Code-provisions have been abundant in Surinamese history. These provisions were much too liberal for Surinamese administrators pursuing agrarian policies. Instead of permitting freehold of land, they allocated - before and after 1869 - plots of land, with requirements concerning crops to be grown. Instead of maintaining a uniform system of individual landholding, structures of collective landholding were accepted to meet the aspirations of ethnic groups or to react to practical problems.

Today, most of the policies to guide landholders have lost their meaning. Contemporary agrarian policies should aim at legal security facilitating agricultural investments. Both part-time peasants living in the city and full-time farmers working in the rural areas should be accommodated. 